\title{
Preparation and Performance Analysis of Foam-concrete Sound Absorbing Material Prepared Purely from Solid Wastes
}

\author{
Jun $\mathrm{Ji}^{1}$, Xiaosheng $\mathrm{Liu}^{2}$, Shengying Tan ${ }^{1}$, Meina Wang ${ }^{1}$, Wen $\mathrm{Ni}^{1}{ }^{*}$ \\ ${ }^{1}$ School of Civil and Resources Engineering, University of Science and Technology Beijing, Beijing 100083, China \\ ${ }^{2}$ Global Energy Interconnection Research Institute Co, LtD Chang-ping district, State Grid Corporation of China, Beijing \\ 102211, China
}

Corresponding Author Email: niwen@ces.ustb.edu.cn

https://doi.org/10.18280/acsm.430106

Received: 19 December 2018

Accepted: 2 February 2019

\section{Keywords:}

foam-concrete, sound absorption performance, industrial solid waste, compressive strength

\section{INTRODUCTION}

Industrialization and modernization are picking up pace, making noise pollution a major type of pollution in the world, alongside with water pollution, air pollution, and solid waste pollution [1]. In fact, noise pollution has become a leading cause of complaints from urban residents. To solve the problem, many materials have been adopted to absorb noises. The popular options include perforated metal sheet, wood fiber board, polyester fiber boards and foam-concrete sound barrier [2-4]. As a new energy-saving, green building material, the foam-concrete stands out for its low cost, corrosion resistance and non-flammability [5]. Nevertheless, this material is constrained by its narrow sound absorption range, and poor sound absorption effect under high compressive strength [6]. These defects can be attributed to the numerous interconnected pores in the concrete, which are the key to the sound absorption of the foam-concrete. It is these pores that create weak links in the material, reducing the compressive strength [7-8]. Therefore, the compressive strength and sound absorption coefficient must be well balanced, such as to design a foam-concrete with lightweight, high-strength and good sound-absorbing effect [9].

At present, the foam-concrete is foamed either physica [10]. However, the physically foamed product might not absorb noises well due to the low connectivity between the pores. As for chemical foaming, autoclaving is needed to enhance the compressive strength, as the foaming process is too unstable to control the pore size. The two foaming methods have been studied separately to improve the sound absorption of foamconcrete [11-12]. For instance, Park S.B. measured the sound absorption coefficient using standing-wave tube and reverberation chamber, and correlated sound absorption coefficient with porosity and frequency [13]. Through theoretical and experimental analysis, Mun and Sungho explored the effects of material diameter, porosity and other influencing factors on the sound absorption properties of porous materials, concluding that small aggregates outperform large ones in sound absorption [14]. Gerharz B. investigated the structure of propylene-modified porous concrete, and verified the excellence of modified porous concrete in noise reduction [15]. To sum up, the physical and chemical foaming methods have rarely been combined to improve the sound absorption effect of foam-concrete.

The strength of foam-concrete has been enhanced primarily in two ways: (1) improving the early strength of foam-concrete with accelerators and early strength agents, thus promoting construction efficiency; (2) replacing part of Portland cement with tailings, and enhancing foam-concrete by the synergistic effect of multiple components. The first strategy has been adopted by the following scholars. Huang et al. mixed silicate and sulfate cement into a foam-concrete with a wet density of $400 \mathrm{~kg} / \mathrm{m}^{3}$ and excellent thermal insulation properties [16]. Taking $\mathrm{NaCl}$ and $\mathrm{Na}_{2} \mathrm{SO}_{4}$ as early strength agents, Su Qian greatly improved the early strength of foam-concrete and applied it successfully in foam-concrete pouring [17]. Some of the representative studies using the second strategy are introduced as follows. Adding fly ash into silicate foamconcrete, Ma et al. significantly reduced the porosity and enhanced the strength of fly ash concrete at $28 \mathrm{~d}$, and the late strength exceeded that of ordinary concrete [18]. He Ting et al. disclosed the effect of steel slag content on the strength of foam-concrete, revealing that the test block surpassed pure cement foam-concrete in $28 \mathrm{~d}$ strength when the steel slag content was lower than $20 \%$ [19]. Cui Xiaowei, Ni Wen and Ren Chao eliminated the foaming process, and produced a material with high compressive strength from steel slag (SS), blast furnace slag (BFS) and desulfurized gypsum (DG) at the mix ratio of 6.2:3:2.8 [20]. In addition, Christina Krämer improved the comprehensive strength of the test material using 
the nanometer $\mathrm{SiO}_{2}$ synthetized by vapor phase method as dispersant, which enhanced the repulsion between particles, reduced the chance of sedimentation and ensured the foam stability. Krämer's research sheds important new light on foam-concrete enhancement [21], because the compressive strength of foam-concretes (density: $300 \sim 800 \mathrm{~kg} / \mathrm{m}^{3}$ ) mostly fall in the low range of $0.5 \sim 5.0 \mathrm{MPa}$.

In light of the above, this paper prepares foam-concrete acoustic panels from base cementitious materials steel slag (SS), blast furnace slag (BFS) and desulfurized gypsum (DG), and explores how fiber and aluminum powder affect the strength and sound absorption of the foam-concrete prepared jointly by physical and chemical foaming.

\section{METHODOLOGY}

\subsection{Raw materials}

In our experiment, the steel slag (SS), blast furnace slag (BFS) and desulfurized gypsum (DG) are respectively produced by Yuhua Iron and Steel Co., Ltd., Xintai Iron \& Steel Corp., Ltd. and Beijing Gypsum Line Plant. The chemical composition of these raw materials was tested. The test results in Table 1 show that the steel slag and mining slag contain lots of silicon and calcium, which is similar to the composition of cement. Our experiment also uses the composite foaming agent produced by Henan Huatai Building Materials Development Co., Ltd, the aluminum powder produced by Handan Silver Spring Aluminum Powder Co., Ltd., and the chopped fiberglass supplied by Nanjing Fiberglass Research \& Design Institute Co., Ltd.

Table 1. Chemical composition of raw materials (\%, mass fraction)

\begin{tabular}{|c|c|c|c|c|c|c|c|c|}
\hline $\begin{array}{c}\text { Materia } \\
1 \\
\end{array}$ & $\begin{array}{c}\mathrm{SiO} \\
2 \\
\end{array}$ & $\begin{array}{c}\mathrm{Al}_{2} \\
\mathrm{O}_{3}\end{array}$ & $\begin{array}{c}\mathrm{Ca} \\
\mathrm{O}\end{array}$ & $\begin{array}{l}\mathrm{Fe}_{2} \\
\mathrm{O}_{3}\end{array}$ & $\begin{array}{c}\mathrm{Mg} \\
\mathrm{O}\end{array}$ & $\begin{array}{c}\mathrm{Mn} \\
\mathrm{O}\end{array}$ & $\begin{array}{c}\mathrm{K}_{2} \\
\mathrm{O}\end{array}$ & $\mathrm{SO}_{3}$ \\
\hline $\begin{array}{c}\text { Blast } \\
\text { furnace } \\
\text { slag }\end{array}$ & $\begin{array}{l}16 . \\
79\end{array}$ & $\begin{array}{c}3.6 \\
1\end{array}$ & $\begin{array}{l}46 . \\
08\end{array}$ & $\begin{array}{c}8.5 \\
6\end{array}$ & $\begin{array}{c}8.0 \\
7\end{array}$ & $\begin{array}{c}1.7 \\
9\end{array}$ & $\begin{array}{l}0.0 \\
75\end{array}$ & $\begin{array}{l}<0 . \\
01\end{array}$ \\
\hline $\begin{array}{c}\text { Steel } \\
\text { slag }\end{array}$ & $\begin{array}{l}34 . \\
65\end{array}$ & $\begin{array}{c}12 . \\
2\end{array}$ & $\begin{array}{l}40 . \\
02\end{array}$ & $\begin{array}{c}0.1 \\
3\end{array}$ & $\begin{array}{l}10 . \\
04\end{array}$ & $\begin{array}{l}11 . \\
44\end{array}$ & $\begin{array}{c}0.4 \\
4\end{array}$ & $\begin{array}{l}<0 . \\
01\end{array}$ \\
\hline $\begin{array}{l}\text { Desulfu } \\
\text { riz-ed } \\
\text { gypsum }\end{array}$ & $\begin{array}{c}1.0 \\
8\end{array}$ & $\begin{array}{c}0.1 \\
1\end{array}$ & $\begin{array}{l}32 . \\
17\end{array}$ & $\begin{array}{c}0.1 \\
6\end{array}$ & $\begin{array}{c}0.2 \\
3\end{array}$ & $\begin{array}{c}0.0 \\
1\end{array}$ & $\begin{array}{l}<0 . \\
01\end{array}$ & $\begin{array}{l}46 . \\
02\end{array}$ \\
\hline
\end{tabular}

\subsection{Pre-processing of raw materials}

The activity of the raw materials, namely the steel slag (SS), blast furnace slag (BFS) and desulfurized gypsum (DG), can be effectively enhanced by increasing the specific surface area (SSA). Taking the mining slag for instance, the growth in SSA is equivalent to the reduction of the particle size. With the increase of the SSA, the grading is optimized, the cementitious materials are more active, the hydration reaction is more complete, and the strength of the cementitious materials is thus enhanced. Studies have shown that the compressive strength of the cementitious materials reaches the maximum when the SSA surpasses $500 \mathrm{~m}^{2} / \mathrm{g}$, but further increase of the SSA to over $600 \mathrm{~m}^{2} / \mathrm{g}$ will cause the materials to agglomerate [22,23], leading to higher energy consumption and poorer mechanical performance. Before our experiment, steel slag (SS), blast furnace slag (BFS) and desulfurized gypsum (DG) were all ground to the SSA of $500 \mathrm{~m}^{2} / \mathrm{g}$ by ball milling and forged grinding as shown in the Figure 1.

The laser diffraction analysis shows that the particle size of the grinded materials averaged at 5 8 $\mu \mathrm{m}$, far below that of ordinary Portland cement $425 \mathrm{~m}^{2} / \mathrm{g}$. On the foam surface, a coating layer was formed by many micron-sized particles, which rapidly participated in the hydration on the foam wall [24], The rapid presetting of the slurry restrained and fixed the bubbles, and maintained the stability of pores.

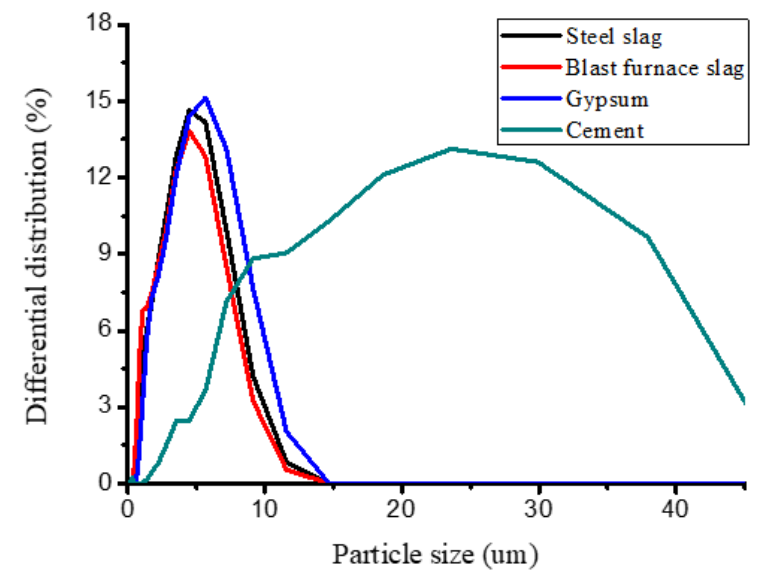

Figure 1. The particle size of the grinded materials and ordinary Portland cement

\subsection{Test procedure}

During the test, the steel slag (SS), blast furnace slag (BFS) and desulfurized gypsum (DG) and aluminum powder were placed into a mixer and mixed for 30s .Then, the mixture was subjected to the addition of fiber and a $45 \mathrm{~s}-$-long stirring, the addition of fiber and a 60s-long stirring, and the addition of aluminum powder and a $15 \mathrm{~s}-$ long stirring. After that, the mixture was added rapidly with foams and stirred evenly, before loaded into the mold. The experiment is matched as shown in the Table 2.

Table 2. Experimental proportioning (\%, mass fraction)

\begin{tabular}{cccccc}
\hline Num & $\begin{array}{c}\text { steel } \\
\text { slag }\end{array}$ & $\begin{array}{c}\text { blast } \\
\text { furnace } \\
\text { slag }\end{array}$ & $\begin{array}{c}\text { desulfurized } \\
\text { gypsum }\end{array}$ & $\begin{array}{c}\text { aluminum } \\
\text { powder }\end{array}$ & $\begin{array}{c}\text { Fiber } \\
\text { glass }\end{array}$ \\
\hline A0 & 38 & 60 & 12 & 0 & 0 \\
A1 & 38 & 60 & 12 & 0 & 1 \\
A2 & 38 & 60 & 12 & 0 & 3 \\
A3 & 38 & 60 & 12 & 0. & 5 \\
B1 & 28 & 60 & 12 & 0.05 & 0 \\
B2 & 28 & 60 & 12 & 0.1 & 0 \\
B3 & 28 & 60 & 12 & 0.15 & 0 \\
C & 38 & 60 & 12 & 0.1 & 3 \\
\hline
\end{tabular}

\section{TEST RESULTS AND DISCUSSION}

\subsection{Effects of fiber on the strength and sound absorption of foam-concrete}

Figure 2 shows that the addition of $1 \%, 3 \%$ and $5 \%$ fiber increased the compressive strength of foam-concrete by $2.35 \%, 5.59 \%$ and $0.588 \%$, respectively, by the $7^{\text {th }}$ day, and $2.16 \%, 7.98 \%$ and $2.50 \%$, respectively, by the $28^{\text {th }}$ day. With the growth in fiber content, the compressive strength of cementitious materials increased first and then declined. This 
trend can be explained as follows. The fiberglass has the properties of a hollow tubular material. The short-chopped fibers are distributed evenly in the slurry, and packed densely by the slurry layer [24]. Thus, the alkali-resistant fiberglass is tensioned in all directions, forming a disordered support system, in which the cementitious materials are bound into a dense 3D network with enhancement effect [25-27]. The disordered support system inside the foam-concrete consists of countless fiber monofilaments. Together, these monofilaments hinder the separation of aggregates and ensure the uniform bleeding of the foam-concrete in the early phase. In this way, more pores are formed and the concrete strength is improved [28]. The excessive growth of fibers may suppress the compressive strength, because the fibers cannot disperse evenly but agglomerate when the fiber density is too high in the foam-concrete.

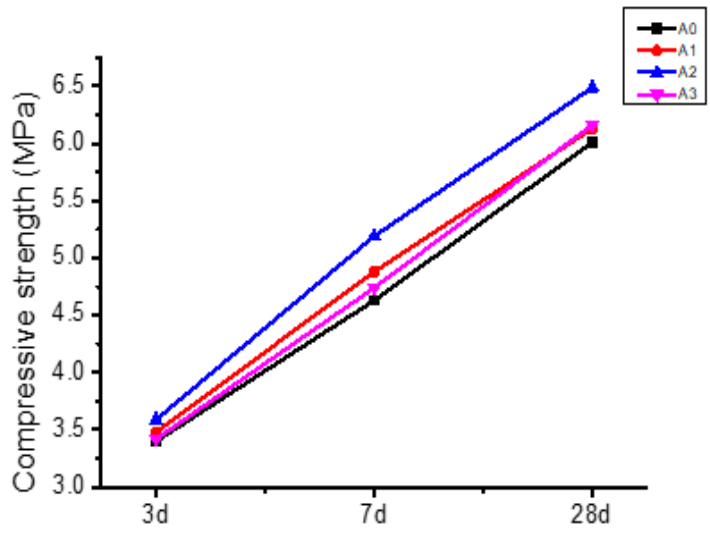

Figure 2. Influence of proportion of fiberglass on strength of concrete

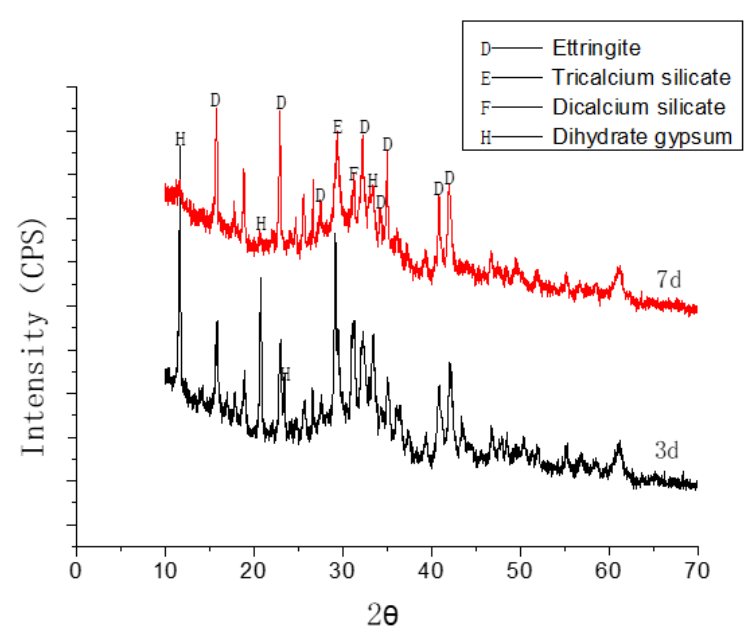

Figure 3. XRD pattern of pastes at different ages

The foam-concretes cured for $3 \mathrm{~d}$ and $7 \mathrm{~d}$ were subjected to X-ray diffraction analysis, aiming to clarify the strength enhancement mechanism of foam-concrete made purely from solid wastes. The results show that the peak strength of ettringite was higher on the $7^{\text {th }}$ day than the $3^{\text {rd }}$ day, indicating that the ettringite was not fully generated on the $3^{\text {rd }}$ day. With the elapse of time, more and more ettringite was produced through hydration in the system of steel slag (SS), blast furnace slag (BFS)and desulfurized gypsum (DG). Meanwhile, the peak strengths of $\mathrm{C}_{2} \mathrm{~S}$ and $\mathrm{C}_{3} \mathrm{~S}$ were smaller on the $7^{\text {th }}$ day than the $3^{\text {rd }}$ day. This means the $\mathrm{C}_{2} \mathrm{~S}$ and $\mathrm{C} 3 \mathrm{~S}$ in the steel slag powder were hydrated, forming the C-S-H gel. For
$\mathrm{CaSO}_{4} \cdot \mathrm{H}_{2} \mathrm{O}$, the main component of FGD gypsum, the peak strength was obviously lower on the $7^{\text {th }}$ day than the $3^{\text {rd }}$ day. This trend reveals that the $\mathrm{Ca}^{2+}$ in FGD gypsum were involved in the hydration reaction, and reacted with the $\mathrm{AlO}_{2}{ }^{-}$from the mining slag, producing ettringite. As shown in the fig.3, undecomposed gypsum was observable on the $3^{\text {rd }}$ day, but almost disappeared on the $7^{\text {th }}$ day, indicating the involvement of decomposed gypsum in hydration. In the later phase, the compressive strength grew slowly, because the growth was mainly driven by ettringite in the system. The formation of ettringite was confirmed by the XRD analysis and scanning electron microscopy (SEM), as shown in the Figure 4.

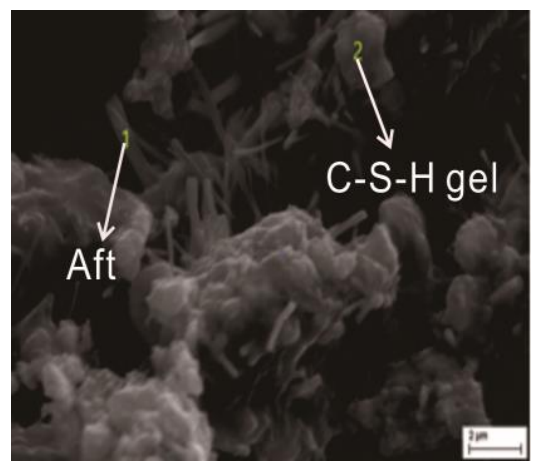

Figure 4. SEM images of hydration products cured for $7 d$

Next, foam-concretes were prepared without fiber, and with $1 \%, 3 \%$ or $5 \%$ of fibers, and measured by standing-wave tube method. The sound absorption coefficients of all specimens were obtained and presented in Figure 5. It can be seen that the cementitious materials foamed without fiber were comparable to ordinary foam-concrete in sound absorption. With the addition of fibers, the foam-concrete did better in absorbing high-frequency noises but poorer facing lowfrequency noises. This is because fibers enjoy strong ability to absorb high-frequency sound waves [29]. The addition of fibers made the foaming system more viscous and harder. What is worse, the fibers could not disperse evenly in the specimens [30]. In the foaming process, the fibers impeded the formation of pores, and thus suppressed the absorption of lowfrequency sound.

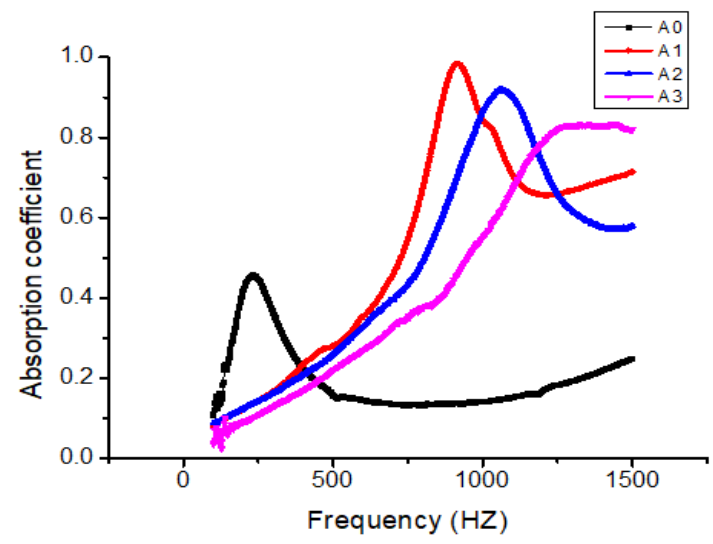

Figure 5. Influence of proportion of fiberglass on sound absorption coefficient of concrete

The above analysis shows that the material boasted a high compressive strength and good sound absorption performance at the fiber content of $3 \%$ : the $28 \mathrm{~d}$ strength amounted to 6.26 $\mathrm{MPa}$ and the mean sound absorption coefficient reached 0.346 . 


\subsection{Effects of physical-chemical combined foaming on the strength and sound absorption of foam-concrete}

As shown in the Figure 6, after adding $0.5 \%$ aluminum powder, the strength of foam-concrete increased by $3.53 \%$, $5.40 \%$, and $8.49 \%$, respectively, on the $3^{\text {rd }}$ day, $7^{\text {th }}$ day and $28^{\text {th }}$ day, from the level of the specimen prepared without aluminum powder. The possible reasons of the strength growth are as follows. With the addition of aluminum powder, the nano-sized aluminum powder reacted rapidly to form microbubbles, making the slurry system more uniform. Meanwhile, the $\mathrm{Al}^{3+}$ replaced the tetrahedron of silicon in the C-S-H gel, turning the latter into a geopolymer [31-32]. The cement slurry between the large bubbles was not severely lost, and many small pores were embedded in the large pores. This integrated two-layer structure enhanced the pore walls, and thus the foam-concrete.

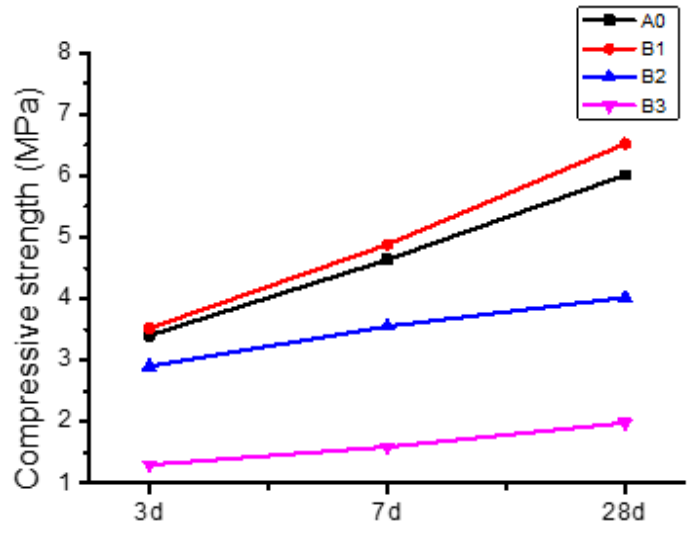

Figure 6. Influence of proportion of aluminum powder on strength of concrete

By contrast, the compressive strength of foam-concrete prepared with $1 \%$ aluminum powder decreased by $14.7 \%$, $23.32 \%$ and $66.89 \%$, respectively, on the $3^{\text {rd }}$ day, $7^{\text {th }}$ day and $28^{\text {th }}$ day, from the level of the specimen prepared without aluminum powder. This is because the growing amount of aluminum powder accelerated the gas generation in a short time. Then, the original foam bubbles expanded, and the pores became interconnected. The heavy presence of interconnected pores is detrimental to the compressive strength.

When the aluminum powder content reached $1.5 \%$, the compressive strength of the foamed cementitious materials was reduced by $61.76 \%, 65.66 \%$ and $67.05 \%$, respectively, on the $3^{\text {rd }}$ day, $7^{\text {th }}$ day and $28^{\text {th }}$ day. The dramatic decline in compressive strength was accompanied by the large expansion of the materials [33], the obvious increase in slurry temperature, the thermal expansion of bubbles and the drastic reduction of material density.

When the aluminum powder content was below $1.5 \%$, the sound absorption of the material was improved obviously with the increase of the dosage as shown in the Figure 7. This is because the closed circular pores prepared by physical foaming were re-opened by the micro-air flows from chemical foaming. The ensuing secondary agglomeration is a recombination of the gas phase, the liquid phase and the solid phase [34-35]. Due to the surface free energy effect, the microand small bubbles formed tiny facture zones, in which bubbles of different diameters continuously clustered into large bubbles, eventually forming interconnected pores. Further addition of aluminum powder and other materials sped up the exothermic chemical reactions [36]. Thus, the foams started to expand irregularly in size and diameter, narrowing the range of effective sound absorption.

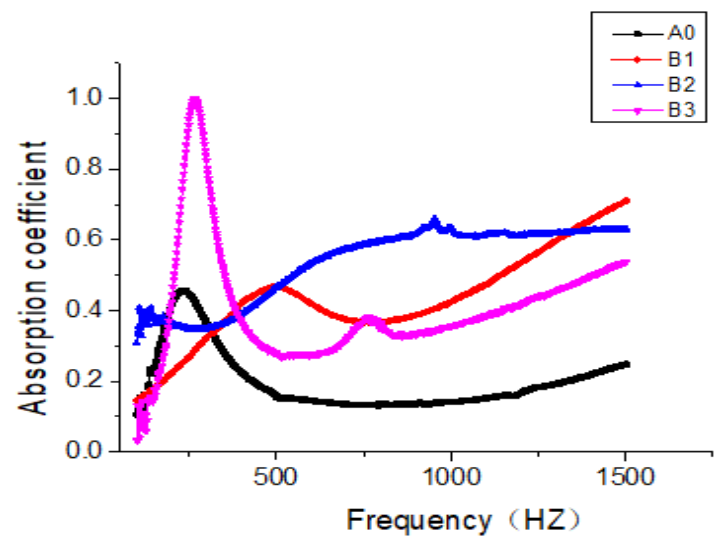

Figure 7. Influence of proportion of aluminum powder on sound absorption coefficient of concrete

3.3 Preparation and mechanism analysis of sound absorbing material based on the optimal mix ratio of steel slag and mining slag

The above analysis demonstrates that physical-chemical combined foaming can effectively improve the sound absorption of foam-concrete. When the dosage of aluminum powder is $1 \%$, the material can withstand the compressive stress of $4 \mathrm{MPa}$, which satisfies the standard for ordinary foam-concrete (A40), and the sound absorption coefficient 0.443 is much higher than that of ordinary foam-concrete.

Next, a sound-absorbing material was prepared with $3 \%$ fibers and $1 \%$ of aluminum powder, and subjected to measurements of compressive strength and sound absorption coefficient. The measurements put the $28 \mathrm{~d}$ compressive strength at $4.99 \mathrm{MPa}$ in the Figure 8 , and the mean sound absorption coefficient at 0.457 as shown in the Figure 9. Through SEM observation in Figure 10, it is learned that the addition of aluminum power created micro airflows between the bubbles, resulting in more interconnected pores, and thus improved the sound absorption performance of the material i. For the foamed cementitious materials based on system of steel slag (SS), blast furnace slag (BFS), the enhancement of compressive strength hinges on the massive generation of ettringite (Aft) and C-S-H gel in Fig4 through hydration, which involves both $\mathrm{C}_{2} \mathrm{~S}$ and $\mathrm{C}_{3} \mathrm{~S}$.

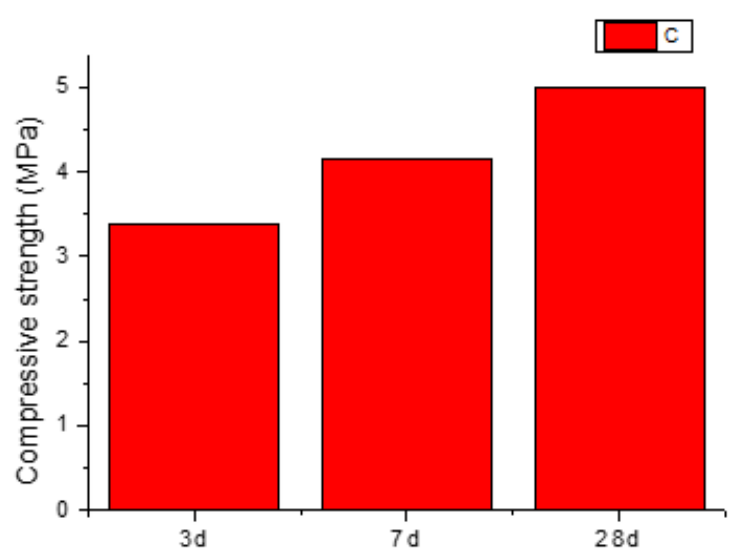

Figure 8. Compressive strength of sample C 


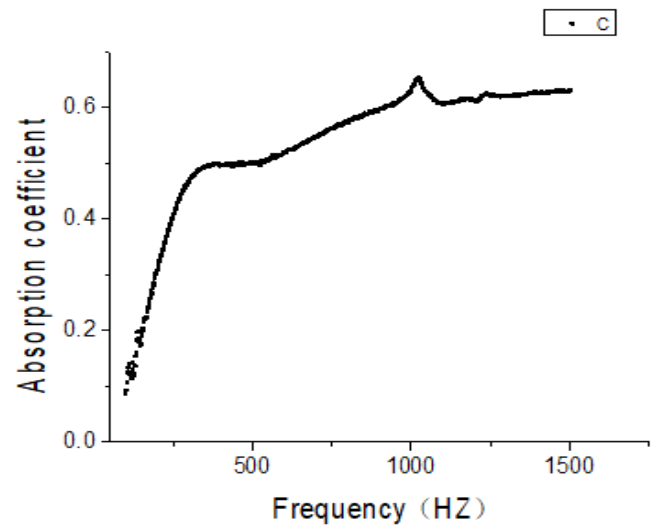

Figure 9. Sound absorption coefficient curve of sample C

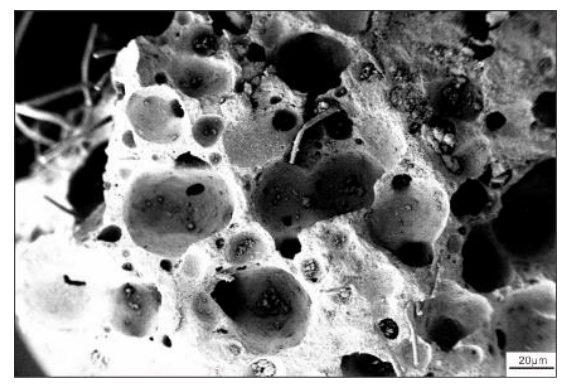

Figure 10. SEM images of pore structure of physicalchemical combined foaming concrete

\section{CONCLUSIONS}

(1) With the growth in fiber content, foam-concrete based on steel slag and mining slag increased first and then declined. Meanwhile, the foam-concrete did better in absorbing highfrequency noises but poorer facing low-frequency noises, and saw a narrower range of effective sound absorption. Considering the heavy presence of high-frequency noise sources in the industrial and construction fields, the bulk density of fiber-containing material should be properly increased to improve the high-frequency absorption ability of the foam-concrete, without violating the strength requirement.

(2) Physical-chemical combined foaming is an effective way to enhance the ability to absorb noises at different frequencies. For the cementitious materials prepared from steel slag and mining slag of the given SSA, the sound absorption performance is optimized as 0.457 at the dosage of $1 \%$ aluminum powder. However, excessive dosage will amplify the heat release of the chemical reactions, leading to a narrow range of effective sound absorption, hurting the sound absorption performance.

Physical-chemical combined foaming creates micro airflows between the bubbles, resulting in more interconnected pores, and thus improves the sound absorption performance of the material. The enhancement of compressive strength of the foam-concrete prepared from steel slag and mining slag comes from the formation of C-S-H gel and ettringite.

\section{ACKNOWLEDGMENT}

The authors would like to thank fund project: State Grid Corporation Headquarters Science and Technology Project Funding.

\section{REFERENCES}

[1] National D, Reform C. (2014). China resources comprehensive utilization annual report. Recyclable Resources and Circular Economy.

[2] Cai CZ, Mak CM. (2018). Noise attenuation capacity of a Helmholtz resonator. Adv. Eng. Softw 116: 60-66. https://doi.org/10.1016/j.advengsoft.2017.12.003

[3] Gwon JG, Kim SK, Kim JH. (2016). Sound absorption behavior of flexible polyurethane foams with distinct cellular structures. Mater. Des 89: 448-454. https://doi.org/10.1016/j.matdes.2015.10.017

[4] Ouis D. (2001). Annoyance from road traffic noise: a review. Journal of Environmental Psychology 21(1): 101-120. https://doi.org/10.1006/jevp.2000.0187

[5] Japan Concrete Institute JCI. (2003). Technical committee report on establishment of design and practical method of porous concrete.

[6] Sukontasukkul P. (2009). Use of crumb rubber to improve thermal and sound properties of pre-cast concrete panel. Constr Build Mater 23(2): 1084-92. https://doi.org/10.1016/j.conbuildmat.2008.05.021

[7] Ranjani IS, Ramamurthy K. (2010). Relative assessment of density and stability of foam produced with four synthetic surfactants. Materials and Structures 43(10): 1317-1325. https://doi.org/10.1617/s11527-010-9582-Z

[8] Nambiar EKK, Ramamurthy K. (2007). Sorption characteristics of foam concrete. Cement and Concrete Research 37(9):

https://doi.org/10.1016/j.cemconres.2007.05.010

[9] Coquard R, Baillis D. (2009). Numerical investigation of conductive heat transfer in high porosity foams. Acta Mater 57(18): 5466-5479. https://doi.org/10.1016/j.actamat.2009.07.044

[10] Duan CY, Cui G, Xu XB, Liu PS. (2012). Sound absorption characteristics of a high-temperature sintering porous ceramic material. Appl Acoust. 73(9): 865-871. https://doi.org/10.1016/j.apacoust.2012.01.004

[11] Kim HK, Lee HK. (2010). Acoustic absorption modeling of porous concrete considering the gradation and shape of aggregates and void ratio. Journal of Sound and Vibration 329(7): 866-879. https://doi.org/10.1016/j.jsv.2009.10.013

[12] Kumar S, García-Triñanes P, Teixeira-Pinto A, Bao M. (2013). Development of alkali activated cement from mechanically activated silico-manganese (SiMn) slag. Cement and Concrete Composites 40: 7-13. http://dx.doi.org/10.1016/j.cemconcomp.2013.03.026

[13] Park SB, Seo DS, Lee J. (2005). Studies on the sound absorption characteristics of porous concrete based on the content of recycled aggregate and target void ratio. Cement and Concrete Research 35(9): 1846-1854. https://doi.org/10.1016/j.cemconres.2004.12.009

[14] Mun S. (2010). Sound absorption characteristics of porous asphalt concrete pavements. Canadian Journal of Civil Engineering 37(2): 273-278. https://doi.org/10.1139/L09-142

[15] Gerharz B. (1999). Pavements on the base of polymermodified drainage concrete. Colloids and Surfaces A: Physicochemical and Engineering Aspects 152(1-2): 205-209. https://doi.org/10.1016/S0927-7757(98)008310

[16] Huang ZY, Sun QF, Zhou ZM. (2013). Study on pore structure and properties of silicate aluminate ultra 
lightweight foamed concrete. Bulletin of the Chinese Ceramic Society 32(9): 1894-1899.

[17] Su Q, Wang YW, Zhao WH, Zhu JJ, Liu J. (2015). Experimental study on the effect of early strength agent on compressive strength and elastic modulus of light weight concrete foam. Railway Engineering (12): 138139 . http://doi.org/10.3969/j.issn.10031995.2015.12.36

[18] Ma KL, Xie YJ, Liu YH. (2007). The influence of fly ash on the porosity and strength of concrete. Coal Ash (5): 35.

[19] He T, Liao HQ, Tong ZS, Song CY, Deng DM, Yu GW, Ba TE. (2013). Effect of steel slag powder on the basic properties of foam concrete. Concrete (11): 75-79. https://doi.org/10.3969/j.issn.1002-3550.2013.11.021

[20] Cui XW, Ni W, Ren C. (2017). Hydration mechanism of all solid waste cementitious materials based on steel slag and blast furnace slag. Chinese Journal of Materials Research 31(9): 688-571. https://doi.org/10.11901/1005.3093.2016.741

[21] Krämer C, Schauerte M, Kowald TL, Trettin RHF. (2015). Three-phase-foams for foam concrete application. Mater. Charact 102: 173-179. https://doi.org/10.1016/j.matchar.2015.03.004

[22] Tsakiridis PE, Papadimitriou GD. (2007). Utilization of steel slag for Portland cement clinker production. Journal of Hazardous Materials 152(2): 805-811. https://doi.org/10.1016/j.jhazmat.2007.07.093

[23] Li GY, Wang PM, Zhao X. (2005). Mechanical behavior and microstructure of cement composites incorporating surface-treated multi-walled carbon nanotubes. Carbon 43(6):

$1239-1245$. https://doi.org/10.1016/j.carbon.2004.12.017

[24] Dinger DR. (2001). Chapter 8: Dense Packing, Particle Calculations for Ceramists, Morris Publishing, United States.

[25] Pyo S, Kim HK. (2017). Fresh and hardened properties of ultra-high performance concrete incorporating coal bottom ash and slag powder. Constr Build Mater 131: $459-466$ http://dx.doi.org/10.1016/j.conbuildmat.2016.10.109

[26] British Standards Institution. (2005). Standard Specification for Admixtures for concrete, mortar and
grout-Test methods: Part 11: Determination of air void characteristics in hardened concrete, BS EN 480-11.

[27] Schober G. (1992). Effect of size distribution of air porosity in AAC on compressive strength. in: A.A. Wittmann (Ed.), Advances in Autoclaved Aerated Concrete, Balkema, Rotterdam 77-81.

[28] Jones MR, Mccarthy A. (2005). Preliminary views on the potential of foamed concrete as a structural material. Mag. Concr. Res 57(1): 21-31. https://doi.org/10.1680/macr.2005.57.1.21

[29] Kucukali-Ozturk M, Ozden-Yenigun E, Nergis B, Candan C. (2017). Nanofiber-enhanced lightweight composite textiles for acoustic applications. J. Ind. Text. 46(7): $1498-1510$ http://dx.doi.org/10.1155/2011/265720

[30] Chen SM, Jiang Y, Chen J, Wang DF. (2015). The effects of various additive components on the sound absorption performances of polyurethane foams. Adv. Mater. Sci. Eng. 2015: 317561. http://dx.doi.org/10.1155/2015/317561

[31] Esmaily H, Nuranian H. (2012). Non-autoclaved high strength cellular concrete from alkali activated slag. Construction and Building Materials 26(1): 200-206. https://doi.org/10.1016/j.conbuildmat.2011.06.010

[32] Liu N, University JN. (2016). Research on defects and improvement measures of foam concrete. Shanxi Architecture (22): 118-120

[33] Xiao LG, Hou QC. (2011). The foam concrete research progress and application. Journal of Jilin Institute of Architecture and Civil Engineering 28(5): 32-36.

[34] Wu H, Ni W, Cui XW, et al. Preparation of concrete sleeper using hot steaming steel slag with low autogenous shrinkage. Transactions of Materials and $\begin{array}{lll}\text { Heat } & \text { Treatment } & \text { 35(4): }\end{array}$ http://dx.doi.org/10.13289/j.issn.1009-6264

[35] Cui XW, Ni W. (2014). Effect of steel slag powder addition on properties of high strength tailings concrete. Metal Mine (9): 177

[36] Bhutta MAR, Tsuruta K, Mirza J. (2012). Evaluation of high-performance porous concrete properties. Constr Build Mater 31: 67-73. https://doi.org/10.1016/j.conbuildmat.2011.12.024 